\title{
O tempo escrito com a pena da galhofa e a tinta da melancolia
}

\section{The time wrote with the pen of mockery and the ink of melancholy}

\section{Ana Lady da Silva*}

Resumo: 0 homem em sua finitude é devorado pelo tempo e marcado pela relação dialética entre 0 "espaço de experiência" e o "horizonte de expectativa", categorias históricas criadas por Reinhart Koselleck, capazes de fundamentar a possibilidade de uma história. A crônica, gênero narrativo que se firmou no Brasil desde meados do século XIX, tece o tempo, a história e a fiç̧ão, a princípio, em coluna de rodapé e gradativamente ganhando espaço nos jornais até transformar-se no que conhecemos hoje. E, pelas mãos de Machado de Assis, retrata com a "pena da galhofa", a "tinta da melancolia" e a "agulha da imaginação", os fatos históricos mais importantes e contraditórios do seu tempo: a escravidão e a Abolição, o Império e a República, as crenças dos antepassados e o avanço da ciência, as velhas ruas alumiadas com azeite de peixe e a urbanização, os antigos hábitos e os novos costumes adquiridos com a vinda da família real em 1808. E, como atesta John Gledson, Machado desejava retratar a natureza e o desenvolvimento da sociedade em que vivia. Passado e futuro em constante embate narrados com o ceticismo do velho bruxo, é a proposta desse trabalho.

Palavras-chave: Machado de Assis; crônica; espaço de experiência; horizonte de expectativa; história.

Abstract: Man in his finitude is devoured by time and labeled by the dialectic relations between "space of experience" and "horizon of expectation", historical categories (created by Reinhardt Koselleck) capable to underlie the possibility of a history. Chronicle, narrative gender that established in Brazil since the middle of the XIXth century, weave time, history and fiction, first at the foot of the printed page, and then achieving more significance in press, until its contemporary meaning. Through Machado de Assis' "pen of mockery", "ink of melancholy" and "needle of imagination", chronicle writing portraits the most important and contradictory historical facts of its time: slavery and the Abolition, Brazilian Empire and Republic, the forebears' beliefs and the march of science, the old streets lightened by fish oil and the urbanization of the city, old habits and new ways of life acquired upon the time of the Portuguese royal family transference to Brazil, in 1808. And, as John Gledson certifies, Machado wished to portrait the nature of development in the society he lived. Past and future in constant fight, narrated by the "old wizard" skeptical eye, is this article proposal.

Keywords: Machado de Assis; chronicle; space of experience; horizon of expectation; history

\section{Crônicas machadianas: o tempo feito texto}

\footnotetext{
*Ana Lady da Silva é professora de Língua Portuguesa do Instituto Federal de Alagoas e Mestra em Estudos Literários pela
} 
A experiência de viver de um homem no mundo remete-nos, inevitavelmente, à ideia de tempo: ao tempo que passou e ao tempo que virá, às experiências que ficam e às expectativas em relação ao desconhecido. Assim, o homem é um ser temporal, finito na sua existência, encerrado na morte.

São coexistentes o tempo cósmico (ou natural) e o tempo histórico e a conexão entre os dois relaciona-se à experiência dos homens no mundo, tanto em sua atuação política, como em suas relações e instituições sociais. O tempo histórico, ao contrário do natural que é único e mensurável pelas ciências, possui uma realidade plural, tão variado quanto a experiência humana. Há diversos "extratos de tempo" que são concomitantes e se superpõem, "estruturas de repetição que não se esgotam na unicidade". ${ }^{1}$ Dessa forma, o tempo histórico não se encerra em uma única resposta, sendo fruto das experiências e expectativas de homens e mulheres.

Trilhando esse caminho de definições históricas, Reinhart Koselleck retoma as duas categorias de Jauss para compreendermos o tempo histórico: espaço de experiência e horizonte de expectativa. Segundo o autor, "Trata-se de categorias do conhecimento capazes de fundamentar a possibilidade de uma história." E continua, "todas as histórias foram constituídas pelas experiências vividas e pelas expectativas das pessoas que atuam ou que sofrem". ${ }^{2}$

Para Koselleck, a história depende da experiência e da expectativa, pois ela é tecida pela "recordação" e pela "esperança", logo, não existe uma sem a existência da outra. "Elas entrelaçam passado e futuro". ${ }^{3}$

A experiência reporta ao passado-presente, cujos acontecimentos foram incorporados pela tradição e podem ser recordados; já a expectativa "se realiza no hoje" e aponta ao não experimentado, ao futuro que pode ser transformado, trazendo consigo "esperança e temor, desejo e vontade, inquietude e curiosidade". ${ }^{4}$

Utilizando-se deste entrelaçamento temporal entre passado - presente - futuro, nos direcionamos para um escritor capaz de tecer os fios da história com a pena da galhofa, a tinta da melancolia e a agulha da imaginação. Machado de Assis, com seus escritos sobre o presente liberal e escravista brasileiro, intercepta o futuro promissor das Luzes, da Ordem e do Progresso, esmigalhando grandes certezas, utopias e otimismos, transformando-os aos poucos no pó das expectativas inúteis. Sua arma: o ceticismo. E o cético, por sua vez, "não tem mestre e não forma discípulos. Ele sabe que as escolas tanto faz políticas, religiosas ou literárias, constituem-se sobre dogmas e não sobre dúvidas" 5 .

\footnotetext{
1 KOSELLECK, Reinhart. Los Extratos de Tiempo: Estudios sobre la história. Barcelona: Paidós Ibérica, 2001. p 68.

2 KOSELLECK, Reinhart. Futuro Passado: contribuição à semântica dos tempos históricos. Rio de Janeiro: Contraponto, 2006, p.306.

3 lbid., p.308.

4 Ibid., p.313.

5 KRAUSE, Gustavo Bernardo. A reação do cético à violência: o caso de Machado de Assis. In: FANTINI, Marli (Org.); Crônicas da Antiga Corte: literatura e memória em Machado de Assis. Belo Horizonte: Editora UFMG, 2008, p.101.
} 
A grande expectativa futurística do Brasil da Belle Époque estava em render culto ao progresso, à modernidade, às novas ideias liberais, abolicionistas e republicanas, embalada pelas novas correntes do determinismo, do darwinismo e pela filosofia positivista de Comte. Ideias importadas da Europa que aqui, na cidade carioca, prometiam o choque entre a tradição e os novos costumes. Deste embate surgiram mudanças na configuração da corte carioca tanto nos modos de agir, pensar, construir e até vestir.

Kátia Muricy, em A Razão Cética, discorre a respeito dessas mudanças, que se iniciaram na transição da colônia ao Império:

A corte do Rio de Janeiro, onde vivem as personagens de Machado de Assis, assistiu a transformações radicais do século. Iniciada com a transferência da corte portuguesa para 0 Brasil, a modernização da cidade acelerou-se no Segundo Reinado: por suas ruas iluminadas a gás passeavam os bondes elétricos [...]. Aberta para uma nova sociabilidade, urbana e cosmopolita, a família iria aos poucos mudar sua feição. [...] os novos hábitos e valores iriam conviver, às vezes conflituosamente, com os antigos costumes da tradição colonial. 6

A vida social brasileira iniciou um processo de modernização depois da vinda da família real que trouxe consigo os novos hábitos já cultuados no velho mundo e que fariam a cabeça da colônia brasileira. A expectativa sobre o novo modo de viver da corte carioca era inevitável, mas ainda era preciso resolver o que fazer com a experiência do presente escravista. Muricy afirma que "O presente ficava suspenso pela urgência de modernizar, civilizar, à moda europeia, os hábitos sociais; um pé no passado, um pé no futuro - eis o nosso solo". ${ }^{7}$ Assim, do princípio ao fim do século XIX, a cidade carioca viveu momentos de grandes contrastes. De um lado, o espaço de experiência: a escravidão e suas mazelas, os hábitos rudes, as ruas ainda alumiadas com azeite de peixe e inundadas pelo "escoadouro de águas servidas dos sobrados", 8 os quiosques de rua que de tudo vendiam, 0 paternalismo, o latifúndio. Do outro, o horizonte de expectativa: o liberalismo, o abolicionismo mal resolvido, a industrialização, as novidades da urbanização das ruas, a ciência, o "desfile de uma variedade inédita de tipos sociais [...] comerciantes, diplomatas, literatos, políticos e artistas estrangeiros

${ }^{6}$ MURICY, Katia. A razão cética: Machado de Assis e as questões do seu tempo. São Paulo: Companhia das Letras, 1988, p.13.

7 lbid., p.34.

${ }^{8}$ FREYRE, Gilberto. Prefácio à Primeira edição. In: Sobrados e Mucambos: decadência do patriarcado rural no Brasil. 15. ed. São Paulo: Global editora, 2004.p.32. 
[...]", ${ }^{9}$ a vestimenta, e até mesmo a ocupação da rua e dos salões por mulheres e homens, daquele século, habituados ao confinamento em suas casas. ${ }^{10}$

Antonio Candido, autor de $A$ vida ao rés-do-chão, não considera a crônica "gênero maior", pois segundo ele: "Não se imagina uma literatura feita de grandes cronistas, que the dessem o brilho universal dos grandes romancistas, dramaturgos e poetas." ${ }^{11}$ Mas acredita que a crônica "pode servir não apenas de caminho para a vida, mas para a literatura." ${ }^{12}$ A respeito da crônica, Candido assevera que:

É curioso como elas mantêm o ar despreocupado, de quem está falando coisas sem consequência; e, no entanto, não apenas entram fundo no significado dos atos e sentimentos do homem, mas podem levar longe a crítica social. ${ }^{13}$

Marlyse Meyer, em Voláteis e Versáteis, afirma ter sido, a princípio, o folhetim ou le feuilleton, ${ }^{14}$ a grande "novidade de Paris", um "espaço vazio destinado ao entretenimento". ${ }^{15} \mathrm{~A}$ autora assevera que, em Paris, "No começo da década de $40^{16}$ a receita está no ponto, é o filé mignon do jornal, grande isca para atrair e segurar os indispensáveis assinantes". ${ }^{17}$ Dessa forma, com o passar do tempo, 0 folhetim adquire nova configuração e se torna responsável pela publicação de todos os romances em forma seriada, facilitando também, a divulgação de jovens autores.

O folhetim parisiense foi "desbatizado" ao chegar em terras brasileiras, é nomeado Folha Literária, Folha História ou Appendix e publicado, no Jornal do Comércio, em outubro de 1838. De acordo com a autora de Voláteis e Versáteis, diferentemente da "gastronomia refinada" francesa, o folhetim brasileiro "é substancioso prato feito, mistura forte", ${ }^{18}$ desmitificando assim prováveis e acentuados preconceitos em relação ao gênero, pois o folhetim nacional seria uma das primeiras formas de passagem do jornal para o livro. Tornou-se aqui também uma das partes mais atrativas do jornal e lançou sucessos como O Guarani e A Viuvinha, no Diário do Rio de Janeiro. E no Correio Mercantil, Manoel Antonio de Almeida, entre os anos de 1852 e 1853, publica Memórias de um

\footnotetext{
9 MURICY, op.cit., p.51.

$10 \mathrm{lbid} ., \mathrm{p} .55$

${ }^{11}$ CANDIDO, Antonio. A vida ao rés-do-chão. In: CANDIDO, Antonio et al. A crônica: 0 gênero, sua fixação e suas transformações no Brasil. Campinas: Editora da Unicamp, 1992, p.13.

12 Ibid., p.14.

13 Ibid., p. $17-18$

14 Inaugurado na França, em 1836, por Giardin, no La Press e depois copiado pelo Le Siècle, o folhetim tinha um lugar preciso no jornal: o rodapé - já nascendo com vocação para o frívolo. Espaço de recreação que abriu portas para 0 "romance rocambolesco" e a fórmula "continua amanhã", entrando no hábito e suscitando expectativas nos leitores.

${ }^{15}$ MEYER, Marlyse. Voláteis e Versáteis: de variedades e folhetins se fez a chronica. In: CANDIDO, Antonio et al. A Crônica: O gênero, sua fixação e suas transformações no Brasil. Campinas: Editora da Unicamp, 1992, p.96.

${ }_{16}^{16}$ Leia-se 1840.

17 MEYER, op.cit., p.98.

18 Ibid., p.102.
} 
Sargento de Milícias. Machado de Assis também lançaria dois de seus romances: A Mão e a Luva, em O Globo, e laiá Garcia, em O Cruzeiro. ${ }^{19}$

Da Europa para o Brasil, a crônica abrasileirou-se, ganhou nova versão, conseguiu espaço nos jornais e tornou-se "praticamente um gênero literário" .20 Machado de Assis num texto intitulado "O nascimento da crônica", em $1^{0}$ de novembro de 1877, aponta a origem do gênero a partir da conversa entre as duas primeiras vizinhas:

\begin{abstract}
Não posso dizer positivamente em que ano nasceu a crônica; mas há toda a probabilidade de crer que foi coetânea das primeiras duas vizinhas. Essas vizinhas, entre o jantar e a merenda, sentaram-se à porta, para debicar os sucessos do dia. Provavelmente começaram a lastimar-se do calor. Uma dizia que não pudera comer ao jantar, outra que tinha a camisa mais ensopada do que as ervas que comera. Passar das ervas às plantações do morador fronteiro, e logo às tropelias amatórias do dito morador, e ao resto, era a coisa mais fácil, natural e possível do mundo. Eis a origem da crônica. ${ }^{21}$
\end{abstract}

Nesse ambiente de descontração, irreverentemente, o cronista compara a crônica a um batepapo entre comadres. E como considera Candido, a crônica "com ar de coisa sem necessidade" pode levar a fundo um momento histórico e a informalidade da escrita, sem rebuscamentos, "que fala de perto ao nosso modo de ser mais natural", aproxima-se do leitor, artifício muito utilizado por Machado em seus escritos, e completa, "na sua despretensão, humaniza". ${ }^{22}$

Não obstante sua aparente descontração e perenidade afirmadas pelo autor de "A vida ao résdo-chão", pois o jornal lido, no dia seguinte, acabaria por "embrulhar um par de sapatos ou forrar o chão da cozinha" ${ }^{23}$ e de não imaginar um Prêmio Nobel atribuído a um cronista, "por melhor que fosse", ${ }^{24}$ as crônicas de muitos autores conseguiram transpor a barreira do tempo e da história e até mesmo as expectativas de muitos críticos, firmando-se nos livros e conquistando cada vez mais espaço entre os pesquisadores nacionais: Lúcia Granja, Sidney Chaloub, John Gledson, Marlyse Mayer, Sonia Brayner entre outros utilizados nesse trabalho.

Contrariando as afirmações oscilantes do renomado crítico de "A vida ao rés-do-chão", acreditamos que as crônicas machadianas compartilham o valor e a visão de seus contos e romances da segunda fase, tendo aquelas, por seu caráter aparentemente "frívolo" e informal, se tornado espécie

\footnotetext{
${ }^{19}$ Assim como muitos romancistas nacionais, Machado inicia, aos vinte anos, sua carreira como folhetinista: em 1859, na revista de literatura, $O$ Espelho, direcionada para modas, indústria e arte.

${ }^{20}$ CRUZ JUNIOR, Dilson Ferreira de. Estratégias e Máscaras de um fingidor: a crônica de Machado de Assis. São Paulo: Nankin Editorial; Humanitas FFLCH/USP, 2002, p.33.

${ }^{21}$ Apud Silva, 2005, p.36.

22 CANDIDO, op. cit., p.3

23 Ibid., p.14.

24 Ibid., p.13.
} 
de ensaio de técnicas narrativas para estes. Lúcia Granja, em Machado de Assis, Escritor em Formação (à roda dos jornais), afirma que não basta apenas "apontar, em geral, o texto da crônica como um 'laboratório de ficção', como uma fonte prática para o desenvolvimento de sua técnica da prosa [...] não basta para que reconheçamos o real valor desses textos de Machado, os quais apresentam, em si e por si, seu interesse". ${ }^{25}$ Ou seja, é preciso creditar valor na crônica.

E diante de tamanha importância alcançada pelo gênero e demonstrada por seus respectivos cronistas e estudiosos, vamos direcionar nossos estudos ao escritor que durante quarenta e um anos (1859 - 1900) dedicou-se à tarefa de "contar histórias" em diversos jornais cariocas como: O Espelho, Diário do Rio de Janeiro, Semana Ilustrada, O Futuro, Ilustração Brasileira, O Cruzeiro e por último, Gazeta de Notícias.

Segundo o crítico John Gledson, as crônicas machadianas são por vezes sarcásticas e pessimistas, sem qualquer tratamento amável para com os assuntos tratados; apesar disso, são levados ao público fatos históricos dignos de reflexão,

[...] são textos de contundente sarcasmo, que assumem uma visão pessimista - pode-se imaginar que seriam chamadas de cínicas e negativas. Se não chegam a ser subversivas, não chegam a ser crônicas amáveis. ${ }^{26}$

Não só as crônicas, mas também os romances machadianos, de acordo com o autor, "pretendem transmitir grandes e importantes verdades históricas, de surpreendente profundidade e amplitude [...] como muitos outros romancistas do século XIX, desejava retratar a natureza e o desenvolvimento da sociedade em que vivia [...]". ${ }^{27}$

E por trás da eventualidade, da frivolidade aparente ou da conversa entre vizinhas é que se escamoteia na crônica machadiana a formação de opinião, o alerta ao leitor para esquivar-se de um olhar fútil sobre o horizonte de expectativa que emerge das novidades da vida social da corte carioca. As conversas com o leitor são antes a busca por uma consciência crítica que se desloca entre a notícia e a ficção, cutuca-o com ironias, aponta para um futuro iluminado nada promissor e, até mesmo, duvidoso.

25 GRANJA, Lúcia. Machado de Assis, Escritor em formação (à roda dos jornais). Campinas: Mercado das Letras; São Paulo: Fapesp, 2000, p.18.

${ }^{26}$ GLEDSON, John. Machado de Assis: Fiç̧ão e História. Rio de janeiro: Paz e Terra, 1986, p.117.

27 Ibid., p.16. 
Ainda segundo John Gledson é a "[...] combinação de paixão e pessimismo que tornam essas crônicas ou algumas delas, tão extraordinárias. 0 conflito entre coração e mente é, em parte, resolvido por um senso de humor quase infalível". ${ }^{28}$

\section{Entre a Escravidão e a Abolição, a Opressão}

As crônicas escritas no mês de maio de $1888{ }^{29}$ são marcadas, principalmente, pelo posicionamento do cronista sobre a Abolição da Escravatura e as suas reais consequências na política e na sociedade. Elas retratam de forma crítica e cética o descumprimento da Lei de Emancipação, pois, mesmo após sua aprovação, alguns senhores não "avisaram" seus escravos sobre a liberdade e os já libertos não sabiam o que fazer com ela, como no caso do sineiro da Glória, outra crônica machadiana. ${ }^{30}$ Machado também rejeita 0 "ingênuo entusiasmo abolicionista" 31 e 0 que pode parecer justiça tardia torna-se expectativa frustrada, já que "O que parece uma mudança fundamental, resultante do idealismo e o triunfo da causa da justiça, acabará por se mostrar como uma forma diferente de opressão" 32. Sobre as crônicas deste ano, Gledson ilustra que,

Fosse em nivel da política nacional (a queda e criação de governos e regimes), de mudanças sociais e econômicas ou da moralidade pessoal, portanto as opiniões de Machado quanto aos eventos de maio de 1888 eram inteiramente céticas. ${ }^{33}$

As crônicas da seção "Bons dias!" "uma mistura do velho e do novo, do permanente e do ocasional" ${ }^{34}$, são de grande importância, devido ao quadro histórico retratado pelo cronista Machado, "porque há nelas um esforço mais consciente para se comprometer com grandes temas históricos, por mais que esse comprometimento seja dissimulado pela ironia". ${ }^{35}$ Por exemplo, a crônica de 11 de maio de 1888 descreve um momento de grande euforia e de festas nas ruas devido aos vários murmúrios

\footnotetext{
28 lbid., p.119.

${ }^{29}$ As crônicas que serão analisadas nesse artigo pertencem ao último periódico Gazeta de Notícias, das seções "Bons dias!" (05 de abril de 1888 a 29 de agosto de 1889) e "A Semana" (24 de abril de 1892 a 28 de fevereiro de 1897; 04 de novembro de 1900 a 11 de novembro de 1900). É importante perceber que, para a identificação e leitura das mesmas, as datas e a seção onde foram escritas são importantes, visto não possuírem título e muitas delas serem assinadas por pseudônimos, recurso bastante usado por Machado, ou ficarem sem assinatura, o que não dificultou seu reconhecimento posterior. Na seção "Bons dias!" o cronista assinava com os "Boas noites!" e a seção "A Semana" ficou sem assinatura. Nesta última, interrompe sua colaboração que fica sob a responsabilidade do colega da fundação da Academia Brasileira de Letras, Olavo Bilac.

30 Publicado originalmente na Gazeta de Notícias, Rio de Janeiro, de 24/04/1892 a 11/11/1900, na seção A Semana, atualmente datada em 04 de novembro de 1897.

31 GLEDSON, op.cit, p.128.

32 GLEDSON, loc.cit.

33 lbid., p.137.

34 GLEDSON, John. Introdução. In: Machado de Assis. Bons Dias! Crônicas 1888-1889. São Paulo: Hucitec; Campinas: Editora Unicamp, 1990, p.25.

35 GLEDSON, loc.cit.
} 
sobre a possível assinatura da Lei Áurea pela princesa Isabel, e as várias alforrias distribuídas pelos senhores que quiseram se antecipar à Emancipação. Estas alforrias antecipadas eram anunciadas nos jornais da época, na seção "A pedidos", e conforme Gledson, uma destas poderia ter inspirado Machado a escrever a crônica sobre o escravo Pancrácio.

Datada em 19 de maio de 1888, publicada na seção Bons dias!,quase uma semana após a assinatura da Lei de Emancipação, Machado aproveita-se das notícias da época e mistura-as aos recursos da ficção para criar o narrador Policarpo, dono do escravo Pancrácio, que momentos antes da assinatura da Lei Áurea decide alforriá-lo.

Na crônica, a princípio, o narrador Policarpo apresenta-se como um descendente de profetas, para explicar o presságio que tivera sobre a Emancipação dos escravos:

Eu pertenço a uma família de profetas après coup, post factum, depois do gato morto, ou como melhor nome tenha em holandês. Por isso digo, e juro se necessário for, que toda a história desta Lei de 13 de Maio estava por mim prevista [...]. 36

Narrada em primeira pessoa, Policarpo é um senhor de escravos, cínico e oportunista, que busca o reconhecimento público por meio de um ato ilustre: a alforria de um escravo seu, "um molecote". Machado dá voz à classe senhorial, marcada com "exagero caricatural", ${ }^{37}$ para minar 0 discurso dominante e desmascarar a "falsa benemerência" dos senhores.

Em Machado de Assis: Bons Dias! Crônicas 1888-1889, Gledson atesta ser comum, nos jornais da época, anúncios de proprietários que desejavam tornar pública sua atitude benevolente para com os africanos escravizados em suas terras, não deixando de mencionar nessas notas públicas, que, o ato digno de exemplo, havia produzido bons resultados, no caso do anúncio abaixo, as cinco filhas da escrava Francisca, "são boas mães de família". Vejamos, então, o anúncio retirado do Jornal Gazeta de Notícias, em 17 de abril de 1888:

\footnotetext{
Liberdade

José Moreira da Silva Rocha, negociante e proprietário do município de Itaguaí, no lugar da ilha da Madeira, em atenção a fazer anos, libertou sua escrava Francisca parda, 45 anos de idade, sem condição alguma, já tendo feito o mesmo a cinco filhas da mesma que hoje são boas mães de família. ${ }^{38}$
}

\footnotetext{
36 DUARTE, Eduardo de Assis. Machado de Assis afrodescendente: escritos de caramujo. Rio de Janeiro: Pallas; Belo Horizonte: Crisálidas, 2007, p.51.

37 DUARTE, loc. cit.

38 GLEDSON, John. Machado de Assis. Bons Dias! Crônicas 1888-1889. São Paulo: Hucitec; Campinas: Editora Unicamp, 1990, p.56.
} 
Na crônica, o narrador Policarpo esnoba ao dizer ter previsto a Lei antecipando-se em alforriar um "molecote que tinha, pessoa de seus dezoito anos, mais ou menos" ${ }^{39}$. De acordo com Gledson, este "mais ou menos" é questionável, pois segundo sua pesquisa, se Pancrácio tivesse dezoito anos "teria nascido antes da Lei do Ventre Livre (28 de setembro de 1871), e, portanto, não sendo ingênuo, valeria mais". 40

A Lei 28 de setembro ficou conhecida como: a Lei Rio Branco ou Lei do Ventre Livre. De acordo com ela, votada em 28 de setembro de 1871, todos os filhos de escravos nascidos a partir daquela data seriam livres. Acompanhemos o primeiro parágrafo:

$\S 1 .^{\circ}$ da lei 2040:- Os ditos filhos menores ficarão em poder e sob a autoridade dos senhores de suas mães, os quais terão a obrigação de criá-los e tratá-los até a idade de oito anos completos. Chegando o filho da escrava a esta idade, o senhor da mãe terá opção, ou de receber do Estado a indenização de $600 \$ 000$, ou de utilizar-se dos serviços do menor até a idade de 21 anos completos. No primeiro caso, o Governo receberá o menor e lhe dará destino, em conformidade da presente lei. 41

De acordo com o parágrafo da Lei, os filhos dos escravos ou ingênuos tinham as seguintes opções: ficavam até os oito anos de idade sob o poder dos donos das mães, com a obrigação de criálos. Após a idade pré-estabelecida, o destino seria decidido pelos mesmos senhores que ou recebiam indenização do governo para liberá-los e a responsabilidade dos filhos dos escravos passaria ao Estado ou os senhores utilizavam-se de seus serviços de mão de obra (escrava) até a maioridade (21 anos). No entanto,

Na prática, os escravocratas mantiveram os ingênuos nas suas propriedades, tratando-os como se fossem escravos. Em 1885, dos 400.000 ingênuos, somente 118 ingênuos foram entregues ao governo - os proprietários optavam por libertar escravos doentes, cegos e deficientes físicos. ${ }^{42}$

O que incomoda na Lei do Ventre Livre é o favorecimento escamoteado aos senhores: 0 pagamento de indenização, ao invés de ser direcionado aos africanos arrancados de suas terras e escravizados em nosso país, era feito aos donos de escravos, que a partir da nova lei, perderiam, teoricamente, a mão de obra lucrativa, no entanto, como percebemos, conseguiram converter o que seria prejuízo em benefícios, pagos pelo próprio governo. Na prática, a libertação gradual dos

\footnotetext{
39 DUARTE, op. cit., p.51.

40 GLEDSON, op.cit., p.62.

41 Disponível em: <http://www.planalto.gov.br/ccivil_03/Leis/LIM/LIM2040.htm > Acesso 16 de março de 2011.

42 Disponível em: <http://pt.wikipedia.org> Acesso em: 16 de março de 2011.
} 
escravos, a começar pelos filhos nascidos após a lei, não ocorreu: muitos foram os recém-nascidos, de escravas, abandonados ou mortos. O prejuízo ficava para ambos os lados: um escravo fora das terras da classe senhorial era pessoa sem valor moral, sem trabalho, sem família ou grupo e sem alimentação, piorando em muito suas condições de vida. As mudanças tão aguardadas pelos abolicionistas não passavam de mais um título no papel da Lei.

Retornando ao narrador e ao molecote Pancrácio, Policarpo decide promover um jantar "a que meus amigos deram o nome de banquete, em falta de outro melhor", ${ }^{43}$ pois já que a alforria lhe faria perder dinheiro "Alforriá-lo era nada; entendi que, perdido por mil, perdido por mil e quinhentos". ${ }^{44} \mathrm{O}$ trecho acima demonstra o falso desapego do dono do escravo ao lucro e à propriedade e decide comemorar com alguns amigos seu ato benevolente: "reuni umas cinco pessoas, conquanto as notícias dissessem trinta e três (anos de Cristo), no intuito de lhe dar um aspecto simbólico". 45

Tanto o tamanho do evento, como a quantidade de convidados e a idade do escravo não são exatos, fazendo com que o leitor duvide o tempo todo das informações fornecidas pelo narrador. Mentir sobre a idade do escravo seria autopromoção, pois se nascido antes da Lei do Ventre-Livre valeria mais e assim a alforria dada ao escravo seria muito mais digna de honrarias e aplausos.

O narrador megalomaníaco tenta convencer a todos ser um modelo a ser copiado, mostra-se seguidor das leis cristãs ao libertar o escravo antecipadamente, porque ironicamente, até a quantidade de convidados é igual à idade de Cristo quando foi crucificado, insinuando, cinicamente, um ambiente santo e puro. A escravidão, portanto, poderia ser considerada um pecado a ser redimido, assim como 0 roubo:

[...] declarei que acompanhando as idéias pregadas por Cristo, há dezoito séculos, restituía a liberdade ao meu escravo Pancrácio; que entendia a que a nação inteira devia acompanhar as mesmas idéias e imitar o meu exemplo; finalmente, que a liberdade era um dom de Deus, que os homens não podiam roubar sem pecado. ${ }^{46}$

O cínico discurso é envolvido por grave frieza e o escravo que espiava tudo, ocultamente, agradece-0, ajoelhando aos pés do dono, como se Policarpo fosse o próprio Cristo, "Pancrácio, que estava à espreita, entrou na sala, como um furacão, e veio abraçar-me os pés". ${ }^{47}$

Todos o brindam na humilde "assembleia" o prestimoso ato, antecedendo as alforrias vindouras: recebe cartões, se faz de modesto "Um dos meus amigos (creio que é ainda meu sobrinho)

${ }^{43}$ DUARTE, op.cit. p.51.

44 DUARTE, loc. cit.

${ }^{4}$ DUARTE, loc. cit.

${ }^{46}$ DUARTE, op.cit. p.51.

47 DUARTE, loc. cit. 
pegou de outra taça, e pediu à ilustre assembleia que correspondesse ao ato que acabava de publicar, brindando ao primeiro dos cariocas". ${ }^{48} 0$ discurso cínico continua, "Creio que estão pintando o meu retrato, e suponho que a óleo". 49

As honrarias, no entanto, ficam para os convidados, pois o verdadeiro discurso prenhe de crueldade é pronunciado somente ao escravo Pancrácio sem argumentos para exigir melhores condições:

No dia seguinte, chamei o Pancrácio e disse-lhe com rara franqueza:

— Tu és livre, podes ir para onde quiseres. Aqui tens casa amiga, já conhecida e tens mais um ordenado, um ordenado que...

— Oh! meu senhô! fico.

_ ... Um ordenado pequeno, mas que há de crescer. Tudo cresce neste mundo; tu cresceste imensamente. Quando nasceste, eras um pirralho deste tamanho; hoje estás mais alto que eu. Deixa ver; olha, és mais alto quatro dedos...

- Artura não qué dizê nada, não, senhô...

- Pequeno ordenado, repito, uns seis mil-réis; mas é de grão em grão que a galinha enche o seu papo. Tu vales muito mais que uma galinha.

- Justamente. Pois seis mil-réis. No fim de um ano, se andares bem, conta com oito. Oito ou sete..$^{50}$

Gledson em Machado de Assis: Bons dias! compara o valor de alguns artigos para demonstrar o baixo valor proposto ao escravo Pancrácio:

[...] uma camisa normal custava 3 mil -réis, o aluguel mensal de uma casa de duas salas, dois quartos, cozinha e quintal, por mês, 35 mil-réis, um almoço ou jantar no Hotel Javanês, quatrocentos réis. A Gazeta de Notícias custava 40 réis. ${ }^{51}$

Estes valores comparativos servem para nos dar uma noção de como seria a transição do trabalho escravo para o assalariado e de como estes recém-libertos teriam muitas dificuldades em fazer parte da sociedade, visto o alto custo de vida na cidade carioca e ínfimos salários pagos.

Juntamente com a aceitação das condições míseras de trabalho e com ordenado humilhante, surge a violência física contra o escravo, validada pelo título adquirido com a liberdade.

48 DUARTE, loc. cit.

49 DUARTE, loc. cit.

50 DUARTE, op.cit., p.52.

51GLEDSON, John. Machado de Assis. Bons Dias! Crônicas 1888-1889. São Paulo: Hucitec; Campinas: Editora Unicamp, 1990, p.63. 
Pancrácio aceitou tudo; aceitou até um peteleco que lhe dei no dia seguinte, por me não escovar bem as botas; efeitos da liberdade. Mas eu expliquei-lhe que o peteleco, sendo um impulso natural, não podia anular o direito civil adquirido por um título que the dei. 52

Ou seja, nada havia mudado: o senhor ainda mandava e o escravo a custa de muitos castigos, justificáveis para os donos, obedecia sem reclamar.

O autor de Machado de Assis afrodescendente: escritos de caramujo assinala ser Pancrácio "um dos mártires e primeiros santos do catolicismo, torturado e decapitado [...] Na Espanha, São Pancrácio é considerado o padroeiro dos trabalhadores". ${ }^{53} \mathrm{O}$ autor afirma também estar este nome vinculado ao substantivo grego pankrátion "que designava uma espécie de luta livre, considerada a modalidade mais violenta do atletismo grego, em que se permitia o uso de mãos e pés a fim de vencer 0 adversário." ${ }^{54}$ Além de sua consonância com a palavra "pancada" no português. ${ }^{55}$

Nome da personagem e momento histórico escolhidos não por acaso pelo cronista carioca que busca por meio da ficção alertar, às avessas, sobre a situação dos africanos alforriados em nosso país que se afirmava liberal; a Emancipação recente que, ao invés de fomentar o desenvolvimento socioeconômico, serviu apenas como mantenedor do mesmo sistema escravista desigual e brutal.

O narrador afirma, logo à frente, ser a liberdade de um a condição para o mau humor do outro, e desta situação, a justificativa para as pancadas, como se natural sempre fora a existência do senhor violento e do escravo conformado, aliás, hierarquia criada por Deus e acertada pelas leis humanas. A violência segue: além da física, também a moral que não parece abalar a permanência do escravo liberto, mas ainda oprimido, na casa do agora patrão. Gledson atesta que "Como no caso de Prudêncio, a escravidão corrompe, e essa corrupção não pode ser curada, simplesmente pela Abolição". 56

Ele continuava livre, eu de mau humor; eram dois estados naturais, quase divinos. Tudo compreendeu o meu bom Pancrácio; daí para cá, tenho-lhe despedido alguns pontapés, um ou outro puxão de orelhas, e chamo-lhe besta quando Ihe não chamo filho do Diabo; coisas todas que ele recebe humildemente, e (Deus me perdoe!) creio que até alegre. ${ }^{57}$

Como assevera Bosi, o trabalho escravo era uma peça fundamental para a economia nacional e os castigos praticados contra os negros eram aceitos e aplicados, indiscutivelmente, com toda a austeridade pelo legítimo dono. No entanto, qualquer ato de rebeldia ou uma mínima ofensa do

\footnotetext{
52 DUARTE, op.cit. p.53.

53 DUARTE, op.cit. p.52.

54 DUARTE, loc. cit.

55 DUARTE, loc. cit.

56 GLEDSON, John. Machado de Assis: Ficção e História. Rio de janeiro: Paz e Terra, 1986, p.137.

57 DUARTE, op.cit. p.52-3.
} 
escravo contra o seu senhor era motivo de pena de morte. Em 1835, "o parlamento liberal-moderado votou uma lei que punia de morte qualquer ato de rebeldia ou de ofensa aos senhores praticado por escravos" ${ }^{58}$. Para 0 crítico, o liberalismo assumido pelo parlamento era apenas uma fachada, pois esse só se afirmaria se fosse "equivalente à ideologia burguesa do trabalho livre", 59 entretanto aqui no Brasil a Independência nem chegou a ser "um conflito interno de classes", ${ }^{60}$ conduzindo a um real liberalismo político, nos transformando assim em um país ambíguo e atrasado em relação aos países desenvolvidos, liberal e escravista. ${ }^{61}$

Policarpo, o narrador-senhor de escravos, continua com seu discurso oportunista, explicitando os reais interesses de sua alforria antecipada: ser deputado e a libertação de Pancrácio, antes da Lei de Emancipação, será seu mote de campanha.

O meu plano está feito; quero ser deputado, e, na circular que mandarei aos meus eleitores, direi que, antes, muito antes de Abolição legal, já eu, em casa, na modéstia da família, libertava um escravo, ato que comoveu a toda a gente que dele teve notícia [...] ${ }^{62}$

E assim como na notícia de jornal em que o dono da escrava Francisca anuncia, de forma exibicionista, terem sido "suas cinco filhas boas mães de família", Machado brilhantemente, copia essa finalização do anúncio oportunista, no entanto, propositalmente exagerado, acentuando a gravidade do discurso frio, sarcástico e conveniente aos interesses da classe senhorial. Sem deixar de alfinetar o Poder Público "sempre retardatário" e inapto em restabelecer a justiça aos africanos trazidos para o nosso país na condição de "coisas" e ao se depararem com uma Libertação tardia e frouxa, esta não Ihes compensa os anos escravizados, não Ihes restitui a mínima dignidade e não lhes traz a cidadania.

[...] que esse escravo tendo aprendido a ler, escrever e contar, (simples suposição) é então professor de filosofia no Rio das Cobras; que os homens puros, grandes e verdadeiramente políticos, não são os que obedecem à lei, mas os que se antecipam a ela, dizendo ao

\footnotetext{
${ }^{58} \mathrm{BOSI}$, Alfredo. A Escravidão entre dois liberalismos. In: A Dialética da Colonização. 4.ed. São Paulo: Companhia das Letras, 1992, p.205.

59 BOSI, loc. cit.

$60 \mathrm{BOSI}$, loc. cit.

61 Segundo Antonio Carlos Mazzeo, "A estrutura escravista era o maior obstáculo para que o liberalismo chegasse a ser a ideologia dominante da sociedade brasileira. Para a burguesia agrária o conceito de sociedade civil limitava-se aos donos de escravos e aos que possuíam capitais e terras. O liberalismo era aceito, apenas, no que se refere ao livre comerciar, mesmo assim, como uma caricatura do europeu, já que a sociedade imperial brasileira era de profundo cunho agrário e, dessa forma, fortemente influenciada por uma ideologia anti-industrialista." MAZZEO, Antonio Carlos. Burguesia e Capitalismo no Brasil. Série Princípios, 2. ed., São Paulo: Ática, 1995, p.18.

62 DUARTE, op.cit., p. 53.
} 
escravo: és livre, antes que o digam os poderes públicos, sempre retardatários, trôpegos e incapazes de restaurar a justiça na terra, para satisfação do Céu. ${ }^{63}$

É este espaço de experiência escravista, injusto e desumano narrado em forma de crônica permeada por fiç̧ão e muita ironia que Machado de Assis retrata o Brasil do Segundo Reinado e desmancha qualquer possibilidade de um horizonte de expectativa repleto de progresso, modernidade e ciência.

\section{O Falso Progresso: sobre bondes e burros}

Classificadas, por Eduardo Assis Duarte, como "Crônicas da Escravidão", as crônicas da seção "A Semana" (assim como as da seção "Bons Dias!"), são textos que marcam um tempo histórico em transição, não somente entre a Abolição e a Escravatura, mas também de transformação da cidade do Rio de Janeiro, caracteristicamente colonial para uma cidade capitalista.

Essas mudanças ocorreram a partir do século XIX e trouxeram nova configuração, não só urbana e espacial, mas também em seu conteúdo. Uma das características marcantes da cidade carioca era a ocupação de uma população majoritariamente escrava e que não possuía meio de transporte coletivo, fazendo com que as elites fossem diferenciadas apenas pelo tipo de moradia, pois todos moravam próximos uns aos outros. ${ }^{64}$

\footnotetext{
O período que se estende de 1870 a 1902 representa, para a história do Rio de Janeiro [...] a etapa inicial de um processo em que esta expansão passa a ser determinada, principalmente, pelas necessidades de reprodução de certas unidades de capital, tanto nacional como estrangeiro. ${ }^{65}$
}

Com o Brasil independente politicamente e o ciclo do café no auge da produção, são atraídos para a cidade do Rio de Janeiro "grande número de trabalhadores livres, nacionais e estrangeiros", 66 além de "numerosos capitais estrangeiros", 67 investidos principalmente no setor de serviços públicos, como os transportes. Somente com instalação dos bondes e trens é que o Rio de Janeiro passar a

\footnotetext{
63 DUARTE, loc. cit.

${ }^{64}$ ABREU. Maurício de A. Evolução Urbana do Rio de Janeiro. Rio de Janeiro: Jorge Zahar Editora, 1987, p.35.

${ }^{65}$ ABREU, loc. cit.

${ }^{66}$ ABREU, loc. cit

${ }^{67}$ ABREU, loc. cit
} 
desenvolver-se com maior velocidade, antes, limitada apenas pelos Morros do Castelo, de São Bento, Conceição e Santo Antonio, regiões alagadas por brejos e mangues. ${ }^{8}$ De acordo com Abreu,

\begin{abstract}
A independência política e o início do reinado do café geram, por sua vez, uma nova fase de expansão econômica, resultando daí a atração - no decorrer do século e em progressão crescente - de um grande número de trabalhadores livres, nacionais e estrangeiros. A partir de meados do século a cidade passa a atrair também numerosos capitais internacionais, cada vez mais disponiveis e á procura de novas fontes de reprodução. Grande parte deles é utilizada no setor de serviços-públicos (transportes, esgoto, gás etc), via concessões obtidas do Estado. 69
\end{abstract}

Ainda segundo o autor, na realidade, esse período de expansão se inicia antes, "em 1868, com a inauguração do primeiro trecho da Estrada de Ferro Dom Pedro II". ${ }^{70}$ As primeiras linhas de bondes puxados por burros foram implantadas a partir de 1868, ampliando a cidade em direção aos bairros da Zona Norte e Sul, mas sobre trilhos de ferro. Em 09/10/1868 foi concedido para a Botanical Garden Railroad Company o serviço de bonde por tração animal (burro), mais tarde conhecida por Companhia de Ferro Carril do Jardim Botânico. Já no final da primeira metade do século XIX, as classes de renda mais alta foram beneficiadas pela ação do poder público que abria e conservava as estradas e caminhos. No entanto, as demais freguesias da cidade "pouco modificaram a sua forma-aparência no período de 1838-1870, continuando a ter um caráter exclusivamente rural". ${ }^{71}$

Após a construção da Estrada de ferro D. Pedro II, o número de trens suburbanos aumentou significativamente, tornando "O ano de 1871 [...] um marco divisório bastante adequado. Trata-se, pois, do ano em que os dois elementos (bondes e trens) passam a atuar sincronicamente" e "permitiram a solidificação de uma dicotomia núcleo-periferia que já se esboçava antes de 1870". ${ }^{72}$ Ferreira dos Santos, citado por Abreu, afirma que o papel destes meios de transporte deve ser relativizado, pois por mais que bondes e trens tenham ampliado a configuração da cidade do Rio de Janeiro, estes "só vieram 'coisificar' um sistema urbano preexistente [...] cujas premissas já estavam prontas em termos de representação ideológica do espaço." Para Ferreira dos Santos "o bonde fez a Zona Sul, porque as razões de ocupação seletiva da área já eram realidade... Já o trem veio responder a uma necessidade de localização de pessoas de baixa renda e de atividades menos nobre". ${ }^{73}$ Este ano marca, não só a

\footnotetext{
68 ABREU, op.cit. p.35

69 ABREU, loc. cit.

70 lbid., p.37.

71 lbid., p.43.

72 lbid., 44.

73 SANTOS apud ABREU, p.44.
} 
ampliação da cidade em termo de vias e transportes, mas também o colapso do sistema escravista, mola mestra da produção nacional. ${ }^{74}$

Conhecer alguns aspectos históricos da cidade carioca e seu crescimento urbano aos princípios do século XIX faz-se mister para compreendermos um pouco das palavras machadianas nas crônicas da Seção "A Semana". Segundo Neves "De uma forma muito particular as crônicas recolocam seus leitores a relação entre ficção e história". ${ }^{75}$

Segundo a autora de "Uma escrita do tempo: Memória, Ordem e Progresso nas crônicas cariocas", as crônicas escritas na passagem do século XIX ao XX podem ser vistas como documento, pois expressam, de certa forma, "um tempo vivido e cheio de transformações e novidades no Rio de Janeiro, trazidas principalmente pela chegada dos bondes elétricos à tração animal e os elétricos". ${ }^{76}$

A palavra bonde foi popularizada pelos cariocas para designar os veículos de transporte, no entanto, originalmente, era usada para nomear os cupons (bonds), vendidos pela empresa concessionária ao público, para evitar problemas com o troco. ${ }^{77}$

Apesar de a eletricidade ter chegado ao Rio de Janeiro, por meio da empresa Light, em 1905, com concessão desde 1899, a cidade de Campos, em 1883, já era beneficiada por uma usina termoelétrica. Em 1891, uma usina elétrica é construída na Tijuca para alimentar os bondes da linha no mesmo lugar. De acordo com a empresa Light,

Há 100 anos a Light chegou ao Brasil para impulsionar o progresso. Autorizada a funcionar em 17 de Julho de 1899, o empreendimento que assinala o início das atividades do Grupo Light no Brasil é a Usina Hidrelétrica Parnaíba, no Rio Tietê, construída entre 1899 e 1901. Para atuar na então Capital Federal, foi fundada, em Toronto, no dia 9 de Junho de 1904, a The Rio de Janeiro Tramway, Light and Power Co. Ltd., que recebeu autorização para funcionar no Rio de Janeiro em 30 de Maio de 1905. Nesse mesmo ano adquiriu o controle acionário da concessionária de iluminação a gás, a empresa belga Société Anonyme du Gaz de Rio de Janeiro, serviço que foi controlado pela Light até 1969, quando foi transferido para o governo estadual. 78

\footnotetext{
74 ABREU, loc. cit.

75 NEVES, Margarida de Souza. Uma escrita do tempo: Memória, Ordem e Progresso nas crônicas cariocas. In: CANDIDO, Antonio et al. A Crônica: o gênero, sua fixação e suas transformações no Brasil. Campinas: Unicamp; RJ: Fundação Casa de Rui Barbosa, 1992, p.76.

76 NEVES, loc. cit

77 ABREU. Maurício de A. Evolução Urbana do Rio de Janeiro. Rio de Janeiro: Jorge Zahar, 1987, p.44

78 Disponível em: <http://www.light.com.br/web/institucional/cultura/seculolight/teseculo.asp> Acesso em: 21 de maio de 2013.
} 
Ainda de acordo com o site da empresa de energia elétrica, Edp do Brasil, ${ }^{79}$ em 1879 é inaugurada, "na Estação Central da Estrada de Ferro D. Pedro II, atual Estrada de Ferro Central do Brasil, a primeira instalação de iluminação elétrica permanente do país." Já em 1883 "Entra em operação a primeira usina hidrelétrica brasileira. A usina está localizada no Ribeirão do Inferno, afluente do rio Jequitinhonha, na cidade de Diamantina." Em 1887, "Entra em operação a usina termoelétrica da Fiat Lux." Em 1889: "Início da operação da primeira hidrelétrica nacional de porte grande para a época, a Marmelos-Zero, da Companhia Mineira de Eletricidade, pertencente ao industrial Bernardo Mascarenhas." Em 1892, "Inauguração da primeira linha de bondes elétricos de caráter permanente do país, no Rio de Janeiro." Em 1899: "Criação da São Paulo Railway, Light and Power Empresa Cliente Ltd - SP Railway -, evidenciando a entrada do capital estrangeiro no setor elétrico".

Anterior e esse momento de modernização da iluminação da cidade por gás e energia elétrica, as ruas eram alumiadas com azeite de peixe. Gilberto Freyre, na obra Sobrados e Mucambos, descreve as ruas do Brasil aos princípios do século XIX:

De noite foi deixando de ser o corredor escuro que os particulares atravessavam com um escravo na frente, de lanterna na mão, para ir se iluminando a lampião de azeite de peixe suspenso por correntes de postes altos. Os princípios da iluminação pública. ${ }^{80}$

Comecemos então a analisar a crônica datada em 16 de outubro de 1892, quatro anos depois da Abolição. Nela, o autor comenta sobre a novidade do momento, sem grande entusiasmo: a chegada dos bondes elétricos. A propósito, o cronista inicia a seção dialogando com o leitor e se explicando sobre o silêncio a respeito do novo transporte: "Não tendo assistido a inauguração dos bondes elétricos, deixei de falar neles. Nem sequer entrei em algum, mais tarde, para receber as impressões da nova tração e contá-las. Daí o meu silêncio da outra semana". ${ }^{81}$ Como é sabido, Machado não valoriza as notícias que costumeiramente estariam nas primeiras páginas dos jornais e sempre acha algo de interessante e digno de reflexão que passa despercebido pelos olhos alheios de outros cronistas.

\footnotetext{
79 Disponível em:

<http://www.edpbr.com.br/energia/pesquisadores_estudantes/energia_eletrica/historia_energia_eletrica/ historia_energia_eletrica.asp> Acesso em: 11 de junho de 2013.

80 FREYRE, Gilberto. Prefácio à Primeira edição. In: FREYRE, Gilberto. Sobrados e Mucambos: decadência do patriarcado rural no Brasil. 15 ed. São Paulo: Global, 2004, p.32.

81 DUARTE, Eduardo de Assis. Estratégias de caramujo. In: (Org.). Machado de Assis afro-descendente: escritos de caramujo. Antologia. Rio de Janeiro: Pallas; Belo Horizonte: Crisálidas, 2007, p.66.
} 
O que chama a atenção do escritor, não é a novidade em si, no caso, o espetáculo da eletricidade conduzindo os novos bondes, mas a discreta atitude do cocheiro do bonde elétrico que passava na contramão,

Anteontem, porém, indo à praia da Lapa, em um bonde comum, encontrei um dos elétricos, que descia. Era o primeiro que estes meus olhos viam andar. Para não mentir, direi o que me impressionou, antes da eletricidade, foi o gesto do cocheiro. 82

E porque o gesto do cocheiro, somente observável a olhos muito atentos, seria mais digno de atenção do que a chegada do progresso? A princípio, o olhar do cocheiro sobre as pessoas que estavam no bonde antigo, seria talvez a representação do olhar do futuro a desdenhar o passado, a sensação da novidade superior,

Os olhos do homem passavam por cima da gente que ia no meu bond, com um grande ar de superioridade. Posto não fosse feio, não eram as prendas físicas que the davam aquele aspecto. Sentia-se nele a convicção de que inventara, não só o bond elétrico, mas a própria eletricidade. ${ }^{83}$

O cronista desacredita das grandes invenções, desdenha da era cientificista, rindo da atitude do homem que tinha convicção de ser o próprio inventor, não só do bonde elétrico, mas da própria eletricidade, a ponto de não querer tirar-lhe a sensação de glória, mesmo que de empréstimo:

Não é meu ofício censurar essas meias glórias, ou glórias de empréstimo, como lhe queiram chamar espíritos vadios. As glórias de empréstimo, se não valem tanto como de plena propriedade, merecem sempre algumas mostras de simpatia. Para que arrancar um homem a essa agradável sensação? Que tenho para lhe dar em troca? ${ }^{84}$

Num segundo momento, o cronista pode admirar melhor o novo meio de transporte, a ponto de poetizar sobre sua locomoção comparando-o a barcos entre brisas,

Em seguida, admirei a marcha serena do bond, deslizando como os barcos dos poetas, ao sopro da brisa invisível e amiga. Mas, como íamos em sentido contrário, não tardou que nos perdêssemos de vista, dobrando ele para o Largo da Lapa e Rua do Passeio, e entrando eu na Rua do Catete. ${ }^{85}$

\footnotetext{
82 lbid., p.66-67.

83 Ibid., p.67.

84 Ibid., p.67.

85 Ibid., p.67.
} 
E como a marcha do passado era contrária a do futuro, ambos perderam-se de vista: espaço de experiência e horizonte de expectativa se cruzam, mas não dialogam, não há pontes para uni-los.

Há apenas o papel da memória capaz de trazer, algum tempo depois, resquícios do momento que já foi presente. Podemos visualizar também o bonde à tração elétrica como representante da República e o de tração animal como o sistema monarquista. Ambos se olham, no entanto, enquanto 0 cocheiro da República se vê como o próprio representante da ciência, do progresso e do avanço tecnológico e segue adiante, deixa o cronista pensativo em relação à situação que se apresenta.

Nem por isso o perdi de memória. A gente do meu bond ia saindo aqui e ali, outra gente entrava adiante e eu pensava no bond elétrico. Assim fomos seguindo; até que, perto do fim da linha e já noite, éramos só três pessoas, o condutor, o cocheiro e eu. Os dois cochilavam, eu pensava. ${ }^{86}$

A genialidade machadiana surge, em seguida, quando ao conduzir o leitor para seu bate-papo costumeiro, como que deslizando entre o bonde elétrico e os seus devaneios, eis que o narrador muda repentinamente a cena de suas reflexões e surge uma alegoria: o encontro entre o passado e o futuro por meio de uma conversa entre os dois burros que tracionavam o bonde antigo onde 0 narrador estava. Alegoria interessante visto os animais que foram escolhidos para o diálogo filosófico, símbolo da completa falta de inteligência e reflexão, a mudança abrupta do assunto exposto pelo cronista, a princípio sobre a modernização da cidade, para outra discussão, a condição de vida dos homens escravizados em nosso país, que em nada acompanhava a evolução da cidade.

O cronista diz ser o único capaz de ouvi-los, alegando conhecer a língua dos burros, ou "a língua dos Houyhnhnms", inserindo intertextualmente os cavalos do romance As viagens de Gulliver, do escritor inglês Jonathan Swift, no qual o protagonista, após um naufrágio, é carregado para uma ilha, Lilliput. Neste romance do século XVIII, Swift critica a sociedade inglesa da época, alegando, por exemplo, que os "Houyhnhnms" eram os verdadeiros sábios, em comparação com a humanidade. $\mathrm{Na}$ ilha, as pessoas eram extremamente pequenas e guerreavam por futilidades. Numa outra terra de gigantes, a mediocridade era tão grande quanto seus habitantes. A ciência também foi duramente criticada pelo escritor, mostrando sua inutilidade frente às necessidades da humanidade. $\mathrm{O}$ cronista continua sua narrativa ficcional: 
pelo que dela conta o famoso Gulliver, não me foi difícil apanhar o diálogo. Bem sei que cavalo não é burro; mas reconheci que a língua era a mesma. 0 burro fala menos, decerto; é talvez o trapista daquela grande divisão animal, mas fala. Fiquei inclinado e escutei: 87

O diálogo, entre os burros, "ouvido" pelo cronista discorre sobre a novidade do momento: a tração elétrica que seria utilizada nos bondes e a tração animal, que consequentemente, logo, seria dispensada e os burros gozariam de liberdade. "- Desde que a tração elétrica se estenda a todos os bonds, estamos livres, parece claro". ${ }^{88}$ No entanto, o outro burro parece não acreditar na bondade humana que mesmo tendo Cristo, como exemplo de conduta para os cristãos, não foi seguido:

- Claro parece; mas entre parecer e ser, a diferença é grande. Tu não conheces a história da nossa espécie, colega; ignoras a vida dos burros desde o começo do mundo. Tu nem refletes que, tendo o salvador dos homens nascido entre nós, honrando a nossa humildade com a sua, nem no dia de Natal escapamos da pancadaria cristã. Quem nos poupa no dia, vinga-se no dia seguinte. 89

O diálogo continua e o burro da direita tenta convencer o burro da esquerda da maldade inerente ao homem, guiado apenas por seus interesses mesquinhos e desumanos; e que continuaria dando chicotadas, mesmo sem a necessidade delas. Percebemos que enquanto o burro da direita se posiciona de forma crítica e por vezes cética em relação às mudanças e melhoras trazidas pelo progresso e pela aclamada recente República, o burro da esquerda apenas analisa os fatos de forma superficial, acreditando em tudo. E este é criticado pelo burro da direita por pensar como os homens: "vejo que há muito de homem nessa cabeça".

—Que tem isso com a liberdade?

- Vejo, redarguiu melancolicamente o burro da direita, vejo que há muito de homem nessa cabeça.

- Como assim? bradou o burro da esquerda estacando o passo. 0 cocheiro, entre dois cochilos, juntou as rédeas e golpeou a parelha.

- Sentiste o golpe? perguntou o animal da direita. Fica sabendo que, quando os bonds entraram nesta cidade, vieram com a regra de se não empregar chicote.

Espanto universal dos cocheiros: onde é que se viu burro andar sem chicote?

Todos os burros desse tempo entoaram cânticos de alegria e abençoaram a ideia os trilhos, sobre os quais os carros deslizariam naturalmente. Não conheciam o homem. 90

\footnotetext{
87 Ibid., p.67.

88 lbid.,p.68.

89 lbid., p.68.

90 Ibid., p.68.
} 
Superficialmente, a narração pode ser entendida, até aqui, apenas como um desabafo entre dois animais cansados das míseras condições de trabalho, das chibatadas e da desvalorização do homem para com o animal, que há tempos tem sido muito útil à humanidade; um deles lembra, inclusive, ter feito parte da cena do nascimento de Cristo: "tendo o salvador dos homens nascido entre nós, honrando a nossa humildade com a sua". Mas, um olhar mais cuidadoso, e podemos perceber outro discurso embutido neste aparente simples diálogo. Podemos interpretar que a chegada dos novos trens à tração elétrica representaria a abolição dos escravos, novidade tão esperada e festejada; e os burros que tracionam o bonde antigo seriam os escravos libertos que o sistema escravagista engoliu novamente, não dando outra opção de trabalho e sobrevivência, a não ser o retorno ao trabalho humilhante.

Machado, nessa crônica, traz por meio de uma fábula ${ }^{91}$ a realidade de um país que vive tristes momentos: foram apenas quatro anos após a assinatura da Lei Áurea e três anos da Proclamação da República e, no entanto, mesmo com a troca de regime, não houve qualquer mudança na condução das políticas públicas e sociais. Anedota parecida com o caso da tabuleta do Custódio e o dizer do Conselheiro Aires, "Também se muda de roupa sem trocar de pele", no romance Esaú e Jacó.

As associações com os escravos são latentes, como as agressões físicas sofridas desde o uso do chicote, passando pelo galho de árvore e a vara de marmeleiro. O burro da esquerda tem uma opinião muito próxima ao da maioria da população da época: por não compreender a situação com um juízo crítico, ele entende ser esta a forma natural de se tratar os bichos e, por analogia, os escravos libertos, que não possuem, mesmo após a Lei de Emancipação, valor humano, sendo reconhecidos ainda como coisas, como bens, movidos à humilhação e a pancadas.

A expressão all right, ao final do trecho selecionado, parece-nos oportuna e cômica, pois sabemos que as mudanças estruturais, de saneamento e de transporte, trazidas para o Brasil, especificamente, na cidade do Rio de Janeiro, durante o século XIX, só foram viabilizadas com o capital estrangeiro e pelas companhias estrangeiras. Segundo a sugestão da crônica, elas "engordariam" os funcionários recém-libertos com "muito feno" e "muito capim", para que os antigos escravos se afeiçoassem à empresa exploradora e não tivessem a chance de se livrarem da exploração. A escravidão continuaria, mas com outras denominações.

\footnotetext{
${ }^{91} \mathrm{~A}$ fábula consiste, de acordo com o dicionário Houaiss, em "curta narrativa em prosa ou verso, com personagens animais que agem como seres humanos e que ilustra um preceito moral." Assim, a fábula consiste em um discurso alegórico, por representar pensamentos e ideias de forma figurada, finalizada por um discurso moral, inferido pelo leitor ou explicado textualmente pelo narrador.
} 
- Sim, o homem imaginou um chicote, juntando as duas pontas das rédeas. Sei também que, em certos casos, usa um galho de árvore ou uma vara de marmeleiro.

- Justamente. Aqui acho razão ao homem. Burro magro não tem força; mas, levando pancada, puxa.

Sabes o que a diretoria mandou dizer ao antigo gerente Shannon? Mandou isto: "Engorde os burros, dê-lhes de comer, muito capim, muito feno, traga-os fartos, para que eles se afeiçoem ao serviço; oportunamente mudaremos de política, all right!"

- Disso não me queixo eu. Sou de poucos comeres; e quando menos trabalho, quando estou repleto. Mas que tem capim com a nossa liberdade, depois do Bond elétrico? ${ }^{92}$

Esse período de transição vem marcado principalmente pelo descaso para com os escravos sem políticas públicas para sua readaptação ao meio social, mas como humano e não como animal de carga. E a evidência textual de que se trata de uma alegoria pode ser observada na sequência do diálogo entre os burros. O burro da direita, ao compreender que eles são "bens da companhia", da mesma forma que os escravos são propriedade dos senhores rurais, tenta esclarecer o burro vizinho que são apenas bens semoventes e, caso os donos achem conveniente, trocam-nos ou vendem-nos.

Mas que tem capim com a nossa liberdade, depois do Bond elétrico?

- $\mathrm{O}$ bond elétrico apenas nos fará mudar de senhor.

- De que modo?

- Nós somos bens da companhia. Quando tudo andar por arames, não somos já precisos, vendem-nos. ${ }^{93}$

Neste trecho do diálogo, o narrador da crônica mostra, de forma irônica, por meio dos animais falantes, o tratamento dado aos africanos como "bens da companhia", desde o princípio da escravidão até os anos após a Emancipação. $O$ diálogo é retomado com uma exclamação do burro da esquerda: "Pela burra de Balaão! [...] exclamou o burro da esquerda. Nenhuma aposentadoria? Nenhum prêmio? Nenhum sinal de gratificação? Oh! mas onde está a justiça deste mundo?". ${ }^{94}$

Entendido aqui como um ser místico ou dotado de poderes milagrosos, o animal é invocado como um ser que pudesse ajudar os companheiros do reino animal na situação desoladora ${ }^{95}$. Talvez

\footnotetext{
92 Ibid., p.68.

93 DUARTE, op.cit., p.68-69.

94 Ibid., p.69.

${ }_{95}$ A burra de Balaão é uma personagem bíblica e em Memórias Póstumas de Brás Cubas, no capítulo "O Delírio", é traduzida como uma asna: no capítulo bíblico era montada por Baalão quando esse se dirigia á terra dos israelitas. Ao surgir um anjo, ela começa a falar e o seu dono converte-se. No romance machadiano, a referência surge quando a personagem Brás Cubas montada no hipopótamo questiona sobre a distância do Início dos Séculos e não obtém resposta "[...] ou não me ouviu, se é que não fingiu uma dessas coisas; e, perguntando-lhe, visto que ele falava, se era descendente do cavalo de Aquiles ou da Asna de Balaão"
} 
até, capaz de fazer um milagre para mudar a atual situação dos burros. A ironia afinada pode estenderse como crítica aos homens ditos cristãos (donos de escravos), pois estes em nada seguem os preceitos religiosos da caridade ou da indulgência, tratando os homens, seres da mesma espécie, como produto de troca, compra e venda, além das demais humilhações decorrentes da situação de escravizados, como os açoites e castigos.

Podemos entender essa crônica como uma crítica contra a falta de políticas públicas a favor dos escravos libertos, como aposentadoria, multa ou benefícios sociais. Nada. Não houve justiça para os negros escravizados e depois libertos. A crítica é assinalada pelas interrogações indignadas do burro da esquerda "Nenhuma aposentadoria? Nenhum prêmio? Nenhum sinal de gratificação?". Então o que restará aos escravos libertos ou aos burros sem emprego? Segundo a conversa entre os burros, "a liberdade de apodrecer", depois de mortos, enfim livres. Mas antes, passarão por outras humilhações: o descaso, tanto por parte dos novos donos que não abrirão mão dos castigos, assim como a velhice, a decrepitude, a miséria, a fome, 0 azar, o abandono...

- Passaremos às carroças - continuou o outro pacificamente — onde a nossa vida será um pouco melhor; não que nos falte pancada, mas o dono de um só burro sabe mais o que ele the custou. Um dia, a velhice, a lazeira, qualquer coisa que nos torne incapaz, restituirnos-á a liberdade...

- Enfim!

- Ficaremos soltos, na rua, por pouco tempo, arrancando alguma erva que aí deixem crescer para recreio da vista. Mas que valem duas dentadas de erva, que nem sempre é viçosa? Enfraqueceremos; a idade ou a lazeira ir-nos-á matando, até que, para usar esta metáfora humana, - esticaremos a canela. Então teremos a liberdade de apodrecer. ${ }^{96}$

O diálogo lúgubre é conduzido em contagem regressiva do momento da morte até a notificação pública e a remoção do cadáver, de forma a parodiar a contagem dos sete dias da criação da vida, do homem e do universo por Deus, segundo a Bíblia:

Ao fim de três, a vizinhança começa a notar que o burro cheira mal; conversação e queixumes. No quarto dia, um vizinho, mais atrevido, corre aos jornais, conta o fato e pede uma reclamação. No quinto dia sai a reclamação impressa. No sexto dia, aparece um agente, verifica a exatidão da notícia; no sétimo, chega uma carroça, puxada por outro burro, e leva o cadáver.$^{97}$

No princípio criou Deus os céus e a terra.

\footnotetext{
96 Ibid., p.69.
}

97 Ibid., p.69. 
[...] Disse Deus: Haja luz; e houve luz.

[...] Chamou Deus à luz Dia e às Trevas, Noite. Houve tarde e manhã, o primeiro dia.

[...] E chamou Deus ao firmamento Céus. Houve tarde a manhã, o segundo dia.

[...] A terra, pois, produziu a relva, ervas que deem semente e árvores frutíferas que deem fruto segundo a sua espécie. [...] E viu Deus que isso era bom. Houve tarde e manhã, 0 terceiro dia [...]. 98

Ao burro da esquerda cabe questionar sobre o papel da esperança, e o da direita responde, "mas a esperança é própria das espécies fracas, como o homem e o gafanhoto". A filosofia, ironicamente, cabe à raça dos burros, ao comparar a humanidade a uma espécie tão fraca quanto a dos gafanhotos. Considerar a espécie humana tão inferior e inofensiva é desmerecê-la, escarnecê-la. A escolha do inseto não foi descuido, visto sabermos que tanto a esperança como 0 animal são verdes. $E$ esta comparação, provoca, consequentemente, o riso no leitor. Machado empresta uma de suas várias vozes fictícias a suas personagens para desmascarar e apontar os desmandos dos senhores e as incongruências de nosso sistema político e social. E o diálogo fica muito próximo ao delírio de Brás Cubas com Pandora a respeito da pretensão humana em pensar, conhecer, viver e descobrir o mundo e a humanidade por meio dos conhecimentos cientificistas.

- Tu és lúgubre, disse o burro da esquerda. Não conheces a língua da esperança.

- Pode ser, meu colega; mas a esperança é própria das espécies fracas, como o homem e o gafanhoto; o burro distingue-se pela fortaleza sem par. A nossa raça é essencialmente filosófica. Ao homem que anda sobre dois pés, e provavelmente à águia, que voa alto, cabe a ciência da astronomia. Nós nunca seremos astrônomos. Mas a filosofia é nossa. Todas as tentativas humanas a este respeito são perfeitas quimeras. Cada século... ${ }^{99}$

O diálogo é interrompido bruscamente, pois o bonde chegara ao ponto final. 0 cronista ainda tenta conversar na língua dos Houyhnhnms, mas é advertido pelo cocheiro para que não espante os animais. No entanto, nos fica uma pergunta: se até o momento, o cronista traduziu toda a conversa que ouvira dos burros, porque nesta exclamação final ele não nos diria o significado da expressão dita aos animais? Lopes, em sua pesquisa, sugere que o diálogo foi interrompido propositalmente, pois parecia que burros e cronista iriam iniciar um diálogo sobre a filosofia de dominação de cada século. E a fala do narrador dirigida aos burros poderia ser traduzida por "sábios cavalos":

\footnotetext{
${ }^{98}$ Bíblia Sagrada. Traduzida em Português por João Ferreira de Almeida. Revista e atualizada na Brasil. Barueri: Sociedade Bíblica do Brasil, 2004.

${ }^{9}$ Ibid., p.69
} 
O diálogo entre os animais é interrompido pelo freio do condutor, quando o personagem parecia iniciar um comentário a respeito da filosofia (de dominação?) de cada século. $O$ freio cala a voz do burro e o silêncio deste permite o e aparecimento da voz do narrador, quando este se aproxima dos animais e profere: “- Houyhnhnms!", ou seja, sábios cavalos! Esses animais, então, ao contrário do senso comum que os via apenas como descendentes de uma casta inferior, não dotados de inteligência, são designados por Machado como sábios, capazes que são de trazer à luz os fatos mais recônditos e de ver para além das aparências. ${ }^{100}$

\section{Considerações Finais}

Segundo Andrade, "Machado buscava nas ruas da cidade moderna imagens-alegoria de uma humanidade que se movia cada vez mais rapidamente nos seus meios de transporte e no seu processo de modernização". 101 O cronista buscava por meio dessa alegoria a compreensão da história de nosso país, marcada por ambiguidades e divergências capazes de conviver lado a lado, assim como o bonde puxado por burros e o por tração elétrica, a escravidão e a abolição, a ciência e a mentalidade retrógrada da nossa classe senhorial. E como assevera Andrade:

O bonde em analogia com a crônica, também passeia pelas ruas, também recorta o olhar diante das paisagens e assuntos que deixa antever pelo caminho, também retrata o tempo como transformação em direção ao novo sob a ameaça constante da alienação. ${ }^{102}$

As crônicas escritas no jornal Gazeta de Notícias foram escolhidas para exemplificarem, em parte, a opinião de Machado de Assis, cronista, sobre seu tempo já que o jornal, veículo de comunicação de fácil acesso, era de grande influência para a sociedade da época e, também, como afirma Gledson, "sustentar que Machado, como muitos outros romancistas do século XIX, desejava retratar a natureza e o desenvolvimento da sociedade em que vivia ". ${ }^{103}$

Segundo o autor de Machado de Assis: Ficção e História há dois aspectos principais que rondam os romances da maturidade de Machado e que denotam a visão do cronista sobre a História da Brasil, período também marcado pela escrita das crônicas,

\footnotetext{
100 LOPES, Elisângela Aparecida. Homem de seu tempo e de seu país: senhores escravos e libertos nos escritos de Machado de Assis. Dissertação de Mestrado, 2007. 171f. Belo Horizonte: POSLIT, Faculdade de Letras da UFMG, 2007, p.138.

${ }^{101}$ ANDRADE, Ana Luíza (Org.). Machado de Assis: crônicas de bond. Chapecó: Argos, 2001, p.91

102 lbid., p.96.

${ }^{103}$ GLEDSON, John. Machado de Assis: Ficção e História. Rio de janeiro: Paz e Terra, 1986, p.16.
} 
Um rígido sistema de classes, baseado na escravidão, que produz uma classe dominante incestuosa, incapaz de renovação procedente dos escalões inferiores e um capitalismo superficial, explorador, com raízes no exterior, incapaz de beneficiar a nação em conjunto, em parte porque esse "conjunto" é uma ficção. 104

E assim o horizonte de expectativas do Brasil foi-se ampliando Segundo Reinado adentro: havia a Medicina combatendo a febre amarela e promovendo a sanitarização das cidades, liderada por Oswaldo Cruz, a elaboração de um código nacional e os institutos históricos escrevendo a história e a memória do país, apoiados pela elite intelectual e econômica de algumas províncias. ${ }^{105}$

Tudo era novidade, mas logo se desmanchou no ar com a pena e a tinta machadianas. Talvez a sua maior obra, considerada pelos críticos como marca de sua maturidade, Memórias Póstumas de Brás Cubas, traga exatamente essa desmistificação do progresso, da verdade e da ciência. A começar pelo "defunto autor" e não "autor defunto", dando-lhe a possibilidade de lançar mão da máscara da falsidade humana, devido ao convívio social, comum entre os vivos, e salpicar o seu veneno, pois por ser um morto não está mais preso às regras sociais, não Ihe importa a opinião alheia. Em seu delírio de morte, percebe que a vida não tem o menor sentido. A natureza atemoriza, é mãe e madrasta; a luta do homem pela felicidade é uma ilusão, assim como a verdade, a ciência, a esperança e o progresso. Muricy afirma sobre este delírio que,

O progresso não existe. Nada, a não ser a crueza do combate em que uns vencem e outros são vencidos é verdadeiro. Não há nada a explicar, como pretende a ciência. Essa ambição explicativa é apenas uma construção para aliviar o homem da falta de sentido da vida. 106

Assim, o homem, em seu vazio constante, busca respostas e na sua eterna ilusão alcança o progresso, inventa a ciência, busca a verdade e se mantém vivo em nome da esperança.

Diante de tais escritos, não podemos ignorar a importância das crônicas machadianas para a feitura posterior de seus romances e contos. Elas serviram como espécie de laboratório e preparação, marcando assim tanto a sua evolução como escritor, como definindo sua marca para a posteridade, "nem que seja de passagem, podemos começar compreender o seu espírito e a sua evolução de escritor". 107

\footnotetext{
104 Ibid., p.22.

105 lbid., p.24.

106 MURICY, Katia. A Razão Cética: Machado de Assis e as questões do seu tempo. São Paulo: Companhia das Letras, 1988, p.102.

107GLEDSON, John. Introdução. In: Machado de Assis. Bons Dias! Crônicas 1888-1889. São Paulo: Hucitec; Campinas: Editora Unicamp, 1990, p.13.
} 
Verificamos que as crônicas machadianas analisadas, anteriormente, são uma mistura única entre notícia e literatura, como afirma Gledson,

De um ponto de vista mais puramente literário (ou de história literária), temos que reconhecer que as crônicas não são puro jornalismo ou reportagem: são como frequentemente se tem dito, um misto híbrido de jornalismo e literatura [...]. 108

\section{Referências Bibliográficas}

ABREU. Maurício de A. Evolução Urbana do Rio de Janeiro. Rio de Janeiro: Jorge Zahar, 1987. ANDRADE, Ana Luíza (Org.). Machado de Assis: crônicas de bond. Chapecó: Argos, 2001. P.86-144. CANDIDO, Antonio. A vida ao rés-do-chão. In: CANDIDO, Antonio et al. A crônica: 0 gênero, sua fixação e suas transformações no Brasil. Campinas: Editora da Unicamp, 1992.

Vários Escritos. São Paulo: Livraria Duas Cidades, 1970.

CHALHOUB, Sidney; NEVES, Margarida de Souza; PEREIRA, Leonardo Affonso de Miranda. (Orgs). História em Cousas Miúdas: Capítulos de História Social da Crônica no Brasil. Campinas: Editora da Unicamp, 2005.

CRUZ JUNIOR, Dilson Ferreira de. Estratégias e Máscaras de um fingidor: a crônica de Machado de Assis. São Paulo: Nankin Editorial; Humanitas FFLCH/USP, 2002.

CZARNOBAY, Andrea Perrot. Machado de Assis e a Ironia: estilo e visão de mundo. Porto Alegre, 2006. 230 f. Tese (Doutorado em Literatura Brasileira) - Faculdade de letras, Universidade Federal do Rio Grande do Sul, 2006.

DUARTE, Eduardo de Assis (Org.). Estratégias de caramujo. In: Machado de Assis afrodescendente: escritos de caramujo. Rio de Janeiro: Pallas; Belo Horizonte: Crisálidas, 2007. FREYRE, Gilberto. Prefácio à Primeira edição. In: FREYRE, Gilberto. Sobrados e Mucambos: decadência do patriarcado rural no Brasil. 15. ed. São Paulo: Global, 2004.

Os Escravos nos Anúncios de Jornais Brasileiros do Século XIX. Recife: Imprensa Universitária, 1963.

GLEDSON, John. Machado de Assis: Ficção e História. Rio de janeiro: Paz e Terra, 1986.

Introdução. In: Machado de Assis. Bons Dias! Crônicas 1888-1889. São Paulo: Hucitec; Campinas: Editora Unicamp, 1990.

GRANJA, Lúcia. Machado de Assis: escritor em formação (à roda dos jornais). Campinas: Mercado das Letras; São Paulo: Fapesp, 2000.

108 Ibid., p.12. 
Das páginas dos jornais aos gabinetes de leitura: rumos dos estudos sobre a crônica de Machado de Assis. Teresa: Revista de Literatura Brasileira, São Paulo, n.6/7, p.385-399, 2006. ISSN1517-9737.

KOSELLECK, Reinhart. Futuro Passado: contribuição à semântica dos tempos históricos. Rio de janeiro: Contraponto, 2006.

KRAUSE, Gustavo Bernardo. A reação do cético à violência: o caso de Machado de Assis. In: FANTINI, Marli (Org.). Crônicas da Antiga Corte: literatura e memória em Machado de Assis. Belo Horizonte: Editora UFMG, 2008.

LOPES, Elisângela Aparecida. Homem de seu tempo e de seu país: senhores escravos e libertos nos escritos de Machado de Assis. 2007. 171f. (Dissertação de Mestrado). Faculdade de Letras da UFMG, Belo Horizonte, 2007.

MEYER, Marlyse. Voláteis e Versáteis: de variedades e folhetins se fez a chronica. In: CANDIDO, Antonio et al. A Crônica: o gênero, sua fixação e suas transformações no Brasil. Campinas: Editora da Unicamp, 1992.

MURICY, Katia. A Razão Cética: Machado de Assis e as questões do seu tempo. São Paulo: Companhia das Letras, 1988.

NEVES, Margarida de Souza. Uma escrita do tempo: memória, ordem e progresso nas crônicas cariocas. In: CANDIDO, Antonio et al. A Crônica: o gênero, sua fixação e suas transformações no Brasil. Campinas: Unicamp; RJ: Fundação Casa de Rui Barbosa, 1992. 